\title{
Segregate of Distinctiveness, Significance and Priority in Ranking
}

\author{
B.Sundarraj, D.Jeyapriya, S.Theivasigamani
}

\begin{abstract}
Information recovery is an ordinary undertaking for various space territory clients for particular undertaking identified with their zone of enthusiasm for information revelation (KDD), Choice makings and so on. Information mining methods plays a essential part to extract data identified with client seek. Web indexes includes in recovering of Users' inquiries via seeking in numerous databases. As the clients of the innovation developing quickly, the huge gathering of information in kind of information joins and keeping up of that information by putting away in databases turned into a major issue for organizations to recover the Information Relevance to the given question, clients are absolutely relying upon the recovery information. Here comes the real issue in assessing the Relevance,Significance and difference of the outcome acquired.

Positioning is the essential idea in showing any outcome on Web based Systems (WS), Automated Systems (AS), Data Retrieval Systems (IRS) by satisfying the basic properties. In this paper we examined in positioning properties, dissimilarity issues and concentrated an approach - Manifold positioning with sink focuses (MRSP) to address assorted variety and in addition pertinence and significance in positioning.
\end{abstract}

\section{Index Terms: KDD, IRS, Ranking, MRSP.}

\section{INTRODUCTION}

Positioning is normally utilized for showing the Webpages at customer side. Positioning has numerous applications in genuine world situation in different fields like Data mining, Data Retrieval and Natural Language Processing. In request to recover a site page identified with client question, which page must be recovered and shown for client is the procedure at web crawler done in light of Relevance , Importance of given question. Excess, Diversity in comes about saw as the essential issues of Ranking. Analysts from different areas have proposed numerous ways to deal with address this issue, for example, Maximum Marginal Relevance (MMR) [1], subtopic decent variety [2], [4], group based centroids choosing [3], arrangement based approach [1], and numerous other excess punishment approaches [6], [5], [7].

Revised Manuscript Received on July 22, 2019.

B.Sundarraj, Department of Computer Science and Engineering, Bharath Institute of Higher education and research, Chennai, India

D.Jeyapriya,, Department of Computer Science and Engineering, Bharath Institute of Higher education and research, Chennai, India

S.Theivasigamani, Department of Computer Science and Engineering, Bharath Institute of Higher education and research, Chennai, India
Notwithstanding, these strategies regularly treat significance and assorted variety independently in the positioning calculation, some of the time with extra heuristic methods. In this paper, we examined a novel approach, named Manifold Ranking with Sink Points (MRSP), to address assorted variety and in addition pertinence and significance in a brought together way. In particular, our approach utilizes a complex positioning procedure over information complex, which can help discover the most pertinent and critical information objects. In the interim, we bring into the complex sink focuses, which are objects whose positioning scores are settled at the base score amid the complex positioning procedure. Along these lines, the positioning scores of different questions near the sink focuses (i.e., objects sharing comparative data with the sink focuses) will be normally punished amid the positioning procedure in view of the natural complex. By handing positioned objects into sink focuses over the information complex, we can adequately avert excess items from accepting a high rank

\section{MATERIALS AND METHODOLOGY}

Complex Ranking calculation works in light of two conditions:

1) Nearby information are probably going to have close positioning scores

2) Data on a similar structure are probably going to have close positioning scores.

I) Description of Ranking Algorithm

A weighted system is built initially, where hubs speak to every one of the information and inquiry focuses, and an edge is put between two hubs in the event that they are "close." Query hubs are at that point started with a positive positioning score, while the hubs to be positioned are doled out with a zero beginning score

\section{RESULTS AND DISCUSSIONS}

Refresh outline is a worldly expansion of theme centered multi record synopsis by concentrating on condensing a la mode data contained in the new archive set given a past record set. Objectives of refresh synopsis.

Pertinence: - The outline must adhere to the subject clients are keen on.

Significance: - The outline needs to disregard minor substance what's more, keep however

much essential data as could reasonably be expected.

Assorted variety: - The synopsis ought to contain less repetitive data and cover

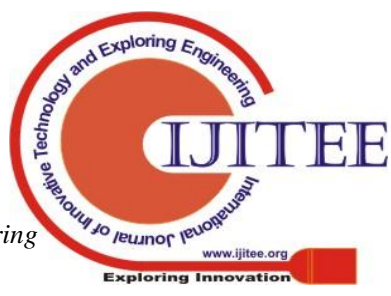




\section{Segregate of Distinctiveness, Significance and Priority in Ranking}

whatever number perspectives as could be expected under the circumstances about the theme.

Curiosity: - The synopsis needs to center around the new data passed on by the later informational index as contrasted and the prior one under that point.

\section{CONCLUSION}

In this paper we considered distinctive methodologies for information complex issues and methodologies that overcomed the current issues and concentrated on the working of MRSP calculation which is one of the fundamental methodologies for settling decent variety issues. We contemplated how MRSP assumes a noteworthy part in positioning pages.

\section{REFERENCES}

[1] Kumarave A., Rangarajan K.,Algorithm for automaton specification for exploring dynamic labyrinths,Indian Journal of Science and Technology,V-6,I-SUPPL5,PP-4554-4559,Y-2013

[2] P. Kavitha, S. Prabakaran "A Novel Hybrid Segmentation Method with Particle Swarm Optimization and Fuzzy C-Mean Based On Partitioning the Image for Detecting Lung Cancer" International Journal of Engineering and Advanced Technology (IJEAT) ISSN: 2249-8958, Volume-8 Issue-5, June 2019

[3] Kumaravel A., Meetei O.N.,An application of non-uniform cellular automata for efficient cryptography,2013 IEEE Conference on Information and Communication Technologies, ICT 2013,V-,I-,PP-1200-1205,Y-2013

[4] Kumarave A., Rangarajan K.,Routing alogrithm over semi-regular tessellations,2013 IEEE Conference on Information and Communication Technologies, ICT 2013,V-,I-,PP-1180-1184,Y-2013

[5] P. Kavitha, S. Prabakaran "Designing a Feature Vector for Statistical Texture Analysis of Brain Tumor" International Journal of Engineering and Advanced Technology (IJEAT) ISSN: 2249-8958, Volume-8 Issue-5, June 2019

[6] Dutta P., Kumaravel A.,A novel approach to trust based identification of leaders in social networks,Indian Journal of Science and Technology,V-9,I-10,PP--,Y-2016

[7] Kumaravel A., Dutta P.,Application of Pca for context selection for collaborative filtering,Middle - East Journal of Scientific Research,V-20,I-1,PP-88-93,Y-2014

[8] Kumaravel A., Rangarajan K.,Constructing an automaton for exploring dynamic labyrinths,2012 International Conference on Radar, Communication and Computing, ICRCC 2012,V-,I-,PP-161-165,Y-2012

[9] P. Kavitha, S. Prabakaran "Adaptive Bilateral Filter for Multi-Resolution in Brain Tumor Recognition" International Journal of Innovative Technology and Exploring Engineering (IJITEE) ISSN: 2278-3075, Volume-8 Issue-8 June, 2019

[10] Kumaravel A.,Comparison of two multi-classification approaches for detecting network attacks, World Applied Sciences Journal,V-27,I-11,PP-1461-1465,Y-2013

[11] Tariq J., Kumaravel A.,Construction of cellular automata over hexagonal and triangular tessellations for path planning of multi-robots,2016 IEEE International Conference on Computational Intelligence and Computing Research, ICCIC 2016,V-,I-,PP--,Y-2017

[12] Sudha M., Kumaravel A.,Analysis and measurement of wave guides using poisson method,Indonesian Journal of Electrical Engineering and Computer Science,V-8,I-2,PP-546-548,Y-2017

[13] Ayyappan G., Nalini C., Kumaravel A.,Various approaches of knowledge transfer in academic social network,International Journal of Engineering and Technology,V-,I-,PP-2791-2794,Y-2017

[14] Kaliyamurthie, K.P., Sivaraman, K., Ramesh, S. Imposing patient data privacy in wireless medical sensor networks through homomorphic cryptosystems 2016, Journal of Chemical and Pharmaceutical Sciences 92.

[15] Kaliyamurthie, K.P., Balasubramanian, P.C. An approach to multi secure to historical malformed documents using integer ripple transfiguration 2016 Journal of Chemical and Pharmaceutical Sciences 92.

[16] A.Sangeetha,C.Nalini,"Semantic Ranking based on keywords extractions in the web", International Journal of Engineering \& Technology, 7 (2.6) (2018) 290-292

[17] S.V.GayathiriDevi,C.Nalini,N.Kumar,"An efficient software verification using multi-layered software verification tool "International Journal of Engineering \& Technology, 7(2.21)2018 454-457

[18] C.Nalini,ShwtambariKharabe,"A Comparative Study On Different Techniques Used For Finger - Vein Authentication", Internationa Journal Of Pure And Applied Mathematics, Volume 116 No. 8 2017, 327-333, Issn: 1314-3395

[19] M.S. Vivekanandan and Dr. C. Rajabhushanam, "Enabling Privacy Protection and Content Assurance in Geo-Social Networks", International Journal of Innovative Research in Management, Engineering and Technology, Vol 3, Issue 4, pp. 49-55, April 2018.

[20] Dr. C. Rajabhushanam, V. Karthik, and G. Vivek, "Elasticity in Cloud Computing", International Journal of Innovative Research in Management, Engineering and Technology, Vol 3, Issue 4, pp. 104-111, April 2018

[21] K. Rangaswamy and Dr. C. Rajabhushanamc, "CCN-Based Congestion Control Mechanism In Dynamic Networks", International Journal of Innovative Research in Management, Engineering and Technology, Vol 3, Issue 4, pp. 117-119, April 2018 .

[22] Kavitha, R., Nedunchelian, R., "Domain-specific Search engine optimization using healthcare ontology and a neural network backpropagation approach", 2017, Research Journal of Biotechnology, Special Issue 2:157-166

[23] Kavitha, G., Kavitha, R., "An analysis to improve throughput of high-power hubs in mobile ad hoc network" , 2016, Journal of Chemical and Pharmaceutical Sciences, Vol-9, Issue-2: 361-363

[24] Kavitha, G., Kavitha, R., "Dipping interference to supplement throughput in MANET" , 2016, Journal of Chemical and Pharmaceutical Sciences, Vol-9, Issue-2: 357-360

[25] Michael, G., Chandrasekar, A.,"Leader election based malicious detection and response system in MANET using mechanism design approach", Journal of Chemical and Pharmaceutical Sciences(JCPS) Volume 9 Issue 2, April - June 2016

[26] Michael, G., Chandrasekar, A.,"Modeling of detection of camouflaging worm using epidemic dynamic model and power spectral density", Journal of Chemical and Pharmaceutical Sciences(JCPS) Volume 9 Issue 2, April - June 2016

[27] Pothumani, S., Sriram, M., Sridhar, J., Arul Selvan, G., Secure mobile agents communication on intranet,Journal of Chemical and Pharmaceutical Sciences, volume 9, Issue 3, Pg No S32-S35, 2016

[28] Pothumani, S., Sriram, M., Sridhar, Various schemes for database encryption-a survey, Journal of Chemical and Pharmaceutical Sciences, volume 9, Issue 3, Pg NoS103-S106, 2016

[29] Pothumani, S., Sriram, M., Sridhar, A novel economic framework for cloud and orid computing, Journal of Chemical and Pharmaceutical Sciences, volume 9, Issue 3, Pg No S29-S31, 2016

[30] Priya, N., Sridhar, J., Sriram, M. "Ecommerce Transaction Security Challenges and Prevention Methods- New Approach" 2016 ,Journal of Chemical and Pharmaceutical Sciences, JCPS Volume 9 Issue 3.page no:S66-S68

[31] Priya, N.,Sridhar,J.,Sriram, M."Vehicular cloud computing security issues and solutions" Journal of Chemical and Pharmaceutical Sciences(JCPS) Volume 9 Issue 2, April - June 2016

[32] Priya, N., Sridhar, J., Sriram, M. "Mobile large data storage security in cloud computing environment-a new approach" JCPS Volume 9 Issue 2. April - June 2016

[33] Anuradha.C, Khanna.V, "Improving network performance and security in WSN using decentralized hypothesis testing "Journal of Chemical and Pharmaceutical Sciences(JCPS) Volume 9 Issue 2 , April - June 2016

[34] Anuradha.C, Khanna.V, "A novel gsm based control for e-devices" Journal of Chemical and Pharmaceutical 
Sciences(JCPS) Volume 9 Issue 2, April - June 2016.

[35] Anuradha.C, Khanna.V, "Secured privacy preserving sharing and data integration in mobile web environments " Journal of Chemical and Pharmaceutical Sciences(JCPS) Volume 9 Issue 2, April - June 2016 .

[36] Sundarraj, B., Kaliyamurthie, K.P. Social network analysis for decisive the ultimate classification from the ensemble to boost accuracy rates 2016 International Journal of Pharmacy and Technology 8

[37] Sundarraj, B., Kaliyamurthie, K.P. A content-based spam filtering approach victimisation artificial neural networks 2016 International Journal of Pharmacy and Technology 83.

[38] Sundarraj, B., Kaliyamurthie, K.P. Remote sensing imaging for satellite image segmentation 2016 International Journal of Pharmacy and Technology 83.

[39] Sivaraman, K., Senthil, M. Intuitive driver proxy control using artificial intelligence2016 International Journal of Pharmacy and Technology 84.

[40] Sivaraman, K., Kaliyamurthie, K.P. Cloud computing in mobile technology 2016 Journal of Chemical and Pharmaceutical Sciences 92.

[41] Sivaraman, K., Khanna, V.Implementation of an extension for browser to detect vulnerable elements on web pages and avoid click jacking 2016 Journal of Chemical and Pharmaceutical Sciences 92.

\section{AUTHORS PROFILE}

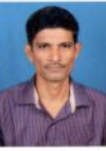

B.Sundarraj, Assistant Professor, Department of Computer Science \& Engineering, Bharath Institute of Higher Education and Research, Chennai, India

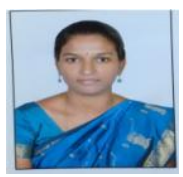

D.JayaPriya Assistant Professor, Department of Computer Science \& Engineering, Bharath Institute of Higher Education and Research, Chennai, India

S.Theivasigamani, Student, Department of Computer Science \& Engineering, Bharath Institute of Higher Education and Research, Chennai, India 